\title{
A synthesis of new 7-amino-substituted \\ 4-aminopyrazolo[1,5-a][1,3,5]triazines via a selective three-component triazine ring annulation $\S$
}

Felicia Phei Lin Lim ${ }^{a}$, Giuseppe Luna ${ }^{b}$, Khai Ching Tan, ${ }^{a}$ Edward R. T. Tiekink ${ }^{c}$, Anton V. Dolzhenko ${ }^{\mathrm{a}, \mathrm{b} *}$

a School of Pharmacy, Monash University Malaysia, Jalan Lagoon Selatan, Bandar Sunway, Selangor Darul Ehsan 47500, Malaysia

b School of Pharmacy and Biomedical Sciences, Curtin Health Innovation Research Institute, Faculty of Health Sciences, Curtin University, GPO Box U1987 Perth, Western Australia 6845, Australia

c Research Centre for Crystalline Materials, School of Science and Technology, Sunway University, Bandar Sunway, Selangor Darul Ehsan 47500, Malaysia

\begin{abstract}
3-Amino-substituted 5-aminopyrazoles were found to be suitable substrates for the synthesis of new 4-aminopyrazolo[1,5-a][1,3,5]triazines (5-aza-9-deaza-adenines) when used in the one-pot, three-component reaction with cyanamide and triethyl orthoformate under microwave irradiation. The reaction proceeded selectively and its scope was demonstrated by the preparation of a library of 4-aminopyrazolo[1,5-a][1,3,5]triazines. Some structural aspects of the prepared compounds were investigated using dynamic NMR spectroscopy and X-ray crystallography. The operational simplicity, short reaction time, and good reproducibility are attractive features of the developed robust and practical approach for the synthesis of 7-amino-substituted 4-aminopyrazolo[1,5-a][1,3,5]triazines.

$\S$ Part 34 in the series "Fused heterocyclic systems with an s-triazine ring." For part 33 see ref. $^{1}$
\end{abstract}




\section{Introduction}

The ubiquitous presence of compounds with the purine scaffold in nature and their regulatory role in many biological processes ${ }^{2}$ inspired work on the development of new bioactive compounds resembling the structures of natural purines. Applied to the $1,3,5-$ triazine based purine analogues, ${ }^{3}$ this strategy has been successfully implemented with the 5-aza-9-deazapurine (pyrazolo[1,5-a][1,3,5]triazine) skeleton. ${ }^{4}$ Compounds with this scaffold often exhibit superior biological activity compared to their purine counterpart. For example, the replacement of purine scaffold with the 5-aza-9-deazapurine improved inhibitory activity $^{5,6}$ and the increased affinity to the enzyme ${ }^{7}$ for cyclin-dependent kinase inhibitors designed as cancer therapeutics. A similar strategy was reported ${ }^{8}$ for the development of a Cav2 voltage gated calcium channel agonist with the 5 -aza-9-deazapurine skeleton. It was significantly more effective than its purine analogue.

In our program on the development of efficient methods for the preparation of new pyrazolo[1,5-a][1,3,5]triazines, ${ }^{9}$ we recently reported a microwave-assisted approach for the synthesis of novel 4-aminopyrazolo[1,5-a][1,3,5]triazine-8-carboxylates $1 .^{9 a}$ Later we found that some of these compounds exhibited promising biological activities (Fig. 1). For example, compounds 1a-d effectively inhibited the Trypanosoma cruzi growth with selectivity for myocardiocyte parasites (Fig 1). ${ }^{10}$

\begin{tabular}{|c|c|c|c|c|}
\hline $\mathrm{NH}_{2}$ & Compound & $\mathrm{R}$ & $\begin{array}{l}\text { T.cruzi growth, } \\
\% \text { inhibition at } 5 \mu \mathrm{M}\end{array}$ & $\begin{array}{l}\text { T.cruzi myocardiocyte parasites per cell, } \\
\% \text { inhibition at } 5 \mu \mathrm{M}\end{array}$ \\
\hline & $1 \mathrm{a}$ & $2-\mathrm{MeOC}_{6} \mathrm{H}_{4}$ & 90 & 92 \\
\hline & $1 \mathrm{~b}$ & $3-\mathrm{MeOC}_{6} \mathrm{H}_{4}$ & 58 & 56 \\
\hline & $1 c$ & $3-\mathrm{ClC}_{6} \mathrm{H}_{4}$ & 65 & 32 \\
\hline & 1d & $4-\mathrm{ClC}_{6} \mathrm{H}_{4}$ & 61 & 53 \\
\hline
\end{tabular}

Figure 1. Bioactive 4-aminopyrazolo[1,5-a][1,3,5]triazine-8-carboxylates 1a-d.

Continuing our research in this direction, we decided to explore importance of the ester group for the observed biological activities. Therefore, we designed decarboxylated analogues, which more closely resemble the adenine structure. Herein, we describe our results on the development of an efficient synthesis of new 4-aminopyrazolo[1,5a] $[1,3,5]$ triazines (5-aza-9-deaza-adenines). 


\section{Results and discussion}

\subsection{Attempts to decarboxylate 4 -aminopyrazolo[1,5-a][1,3,5]triazine-8-carboxylates 1}

Having alkyl 4-aminopyrazolo[1,5-a][1,3,5]triazine-8-carboxylates 1 prepared earlier, ${ }^{9 a}$ we initially attempted to involve ethyl 4-aminopyrazolo[1,5-a][1,3,5]triazine-8-carboxylate (1e) into a hydrolytic decarboxylation of the ester group to prepare the corresponding adenine analogue 4 a. However, heating 1 e in aqueous hydrochloric acid resulted in the formation of 2 as a product of hydrolytic deamination at the triazine ring, while the ester group remained intact (Scheme 1). A similar outcome (formation of 2, 29\%) was achieved when hydrochloric acid was replaced with sulphuric acid of the same concentration. The peaks of the amino group of the starting $1 \mathrm{e}$ were replaced in ${ }^{1} \mathrm{H}$ NMR spectrum of $\mathbf{2}$ by a downfield shifted signal of the triazine ring $\mathrm{N}-\mathrm{H}$ at $13.04 \mathrm{ppm}$, which together with the carbonyl group peak at $163.8 \mathrm{ppm}$ in the ${ }^{13} \mathrm{C}$ NMR spectrum, confirmed the structure assignments. The ethoxycarbonyl group signals in the NMR spectra of 2 remained present.<smiles>CCOC(=O)c1c(Nc2ccccc2)nn2c(N)ncnc12</smiles>

$1 e$
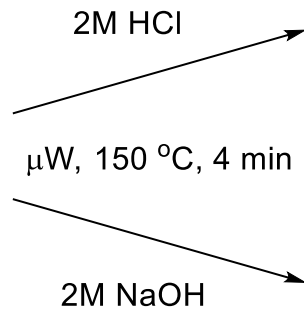
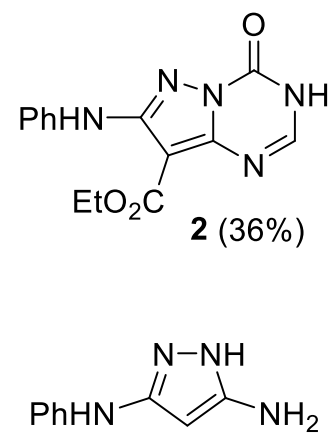

$3 a(52 \%)$

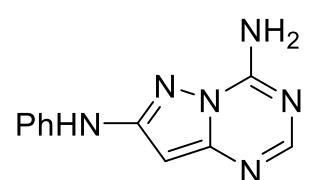

4a (not formed)

Scheme 1. Acid and base-catalysed hydrolytic decomposition of ethyl 4-aminopyrazolo[1,5a] $[1,3,5]$ triazine-8-carboxylate $\mathbf{1 e}$.

More complex transformations were observed when $\mathbf{1 e}$ was treated with alkali under similar microwave conditions (Scheme 1). The hydrolysis and decarboxylation of 1e were achieved under these conditions, but they were also destructive for the triazine ring affording 5-amino-3-phenylaminopyrazole (3a). We concluded that high electrophilicity of the triazine ring in 4-aminopyrazolo[1,5-a][1,3,5]triazine-8-carboxylates 1 made them less suitable for the initially proposed decarboxylation pathway. However, the isolated 5-amino- 
3-phenylaminopyrazole (3a) appeared to be a suitable substrate for our previously developed three-component reaction of aminopyrazoles with cyanamide and orthoformate. This reaction could potentially lead to the formation of the desired $\mathbf{4 a}$. Moreover, once $\mathbf{1 e}$ was effectively converted to $\mathbf{3 a}$, the pyrazole precursor of $\mathbf{1 e}$ viz. 5-amino-3phenylaminopyrazole-4-carboxylate $\mathbf{5} \mathbf{a}^{11}$ was also explored as a substrate and was successfully involved in the hydrolytic decarboxylation under similar conditions. ${ }^{12}$ Therefore, we decided to explore this pathway for the synthesis of adenine analogues 4 (Scheme 2).

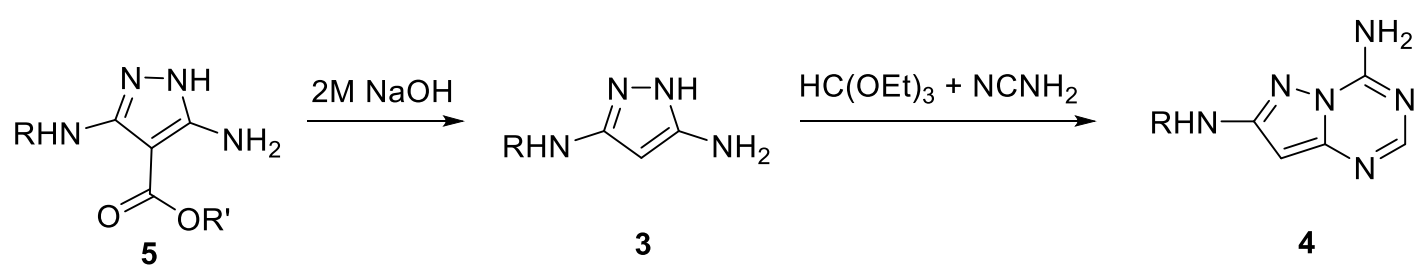

Scheme 2. Proposed approach for the synthesis of 5-aza-9-deaza-adenines 4.

\subsection{Synthesis of 5-aza-9-deaza-adenines 4}

We prepared 3-amino-substituted 5-aminopyrazoles $(3)^{12}$ and attempted to use them as substrates for the one-pot multicomponent reaction (MCR) with cyanamide and triethyl orthoformate. Unlike 4-substituted 5-aminopyrazoles, compounds $\mathbf{3}$ have one more nucleophilic centre at C-4, which is additionally activated by two amino groups at the neighbouring carbon atoms. This centre increases the complexity of heterocyclizations for 5aminopyrazoles in the proposed reaction, potentially resulting in the formation of four products 4 and 6-8 (Scheme 3). However, an attempt to carry out this reaction under microwave irradiation at $150{ }^{\circ} \mathrm{C}$ for $20 \mathrm{~min}$ in methanol using $\mathbf{3 a}$ as a substrate led to the successful formation of the desired 4-amino-7-phenylaminopyrazolo[1,5-a][1,3,5]triazine (4a) and no products of the pyrimidine ring annulation (7 and 8) were detected. Their structures were excluded on the basis of spectral data, particularly by the presence of characteristic $\mathrm{H}-8$ signal at 5.56-6.09 ppm in ${ }^{1} \mathrm{H}$ NMR spectra and $\mathrm{HMBC}$ data for representative compounds. The X-ray crystallographic data (vide infra) excluded regioisomeric structure 6 and unambiguously confirmed formation of compounds 4 . 


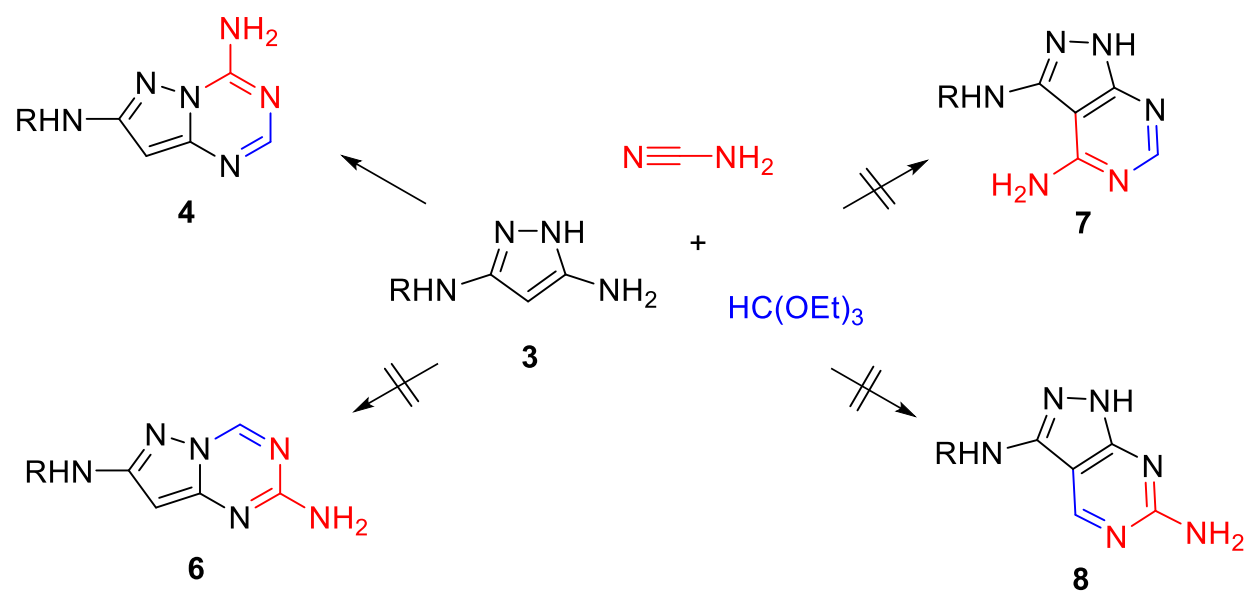

Scheme 3. Potential outcomes of the MCR of $\mathbf{3}$ with triethyl orthoformate and cyanamide.

The initial attempt of the MCR with 5-amino-3-phenylaminopyrazole (3a), triethyl orthoformate and cyanamide afforded $4 a$ in $49 \%$ yield (Table 1). Despite the moderate yield, product 4a was isolated in pure form without a need of chromatographic purification. Further optimising of the reaction conditions, we found that through manipulation with reaction time (Table 1, entries 1-3), the yield could be improved to $60 \%$ by performing the reaction at $150{ }^{\circ} \mathrm{C}$ for $25 \mathrm{~min}$ (Entry 2). However, conducting the reaction in different solvents (Entries 4 and 5) did not increase in yield. Attempts to manipulate with the ratio of reagents (Entries 6 and 7) and temperature of reaction (Entries 8 and 9) also did not lead to further improvements in the reaction outcome.

The developed method was optimised using Discover SP (CEM) microwave synthesizer and was further tested using another microwave reactor, Monowave 400 (Anton Paar). The three-component reaction of $\mathbf{3 a}$, triethyl orthoformate and cyanamide under the optimized conditions resulted in the formation of $\mathbf{4 a}$ in similar yields in the both microwave systems (60\% and 56\%, respectively). To further assess the importance of microwave irradiation for the reaction outcome, we also attempted to carry out the MCR of 3a, triethyl orthoformate and cyanamide in sealed vessels under pressurized, fast, conventional heating. The Monowave 50 (Anton Paar) reactor, imitating the heating pattern of the earlier optimised microwave irradiation conditions, was found to be suitable for this purpose. It led to the successful formation of equally pure 4 a was obtained in $53 \%$ yield. Therefore, we could exclude any significant contribution of non-thermal microwave effects in promoting this MCR. 
Table 1. Optimization conditions for the synthesis of 4-amino-7-phenylaminopyrazolo[1,5a] $[1,3,5]$ triazine $(4 a)^{\text {a }}$

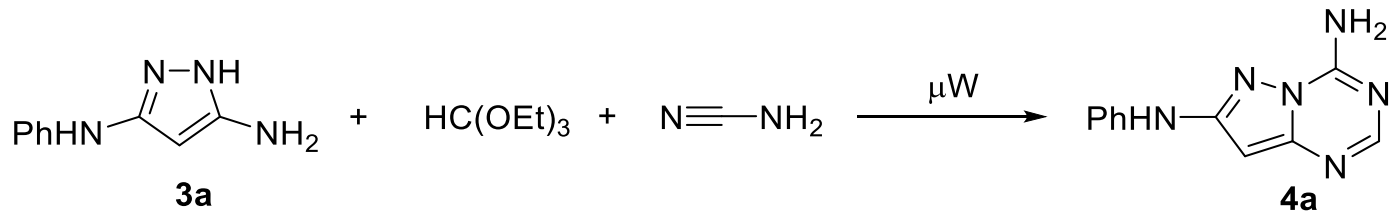

\begin{tabular}{|c|c|c|c|c|c|}
\hline Entry & Solvent & $\begin{array}{l}\text { Ratio of 3a: } \\
\mathrm{HC}(\mathrm{OEt})_{3}: \mathrm{NCNH}_{2}\end{array}$ & Temperature $\left({ }^{\circ} \mathrm{C}\right)$ & Time (min) & $\begin{array}{l}\text { Isolated } \\
\text { yield (\%) }\end{array}$ \\
\hline 1 & $\mathrm{MeOH}$ & 1:1.8:1.2 & 150 & 20 & 49 \\
\hline 2 & $\mathrm{MeOH}$ & 1:1.8:1.2 & 150 & 25 & 60 \\
\hline 3 & $\mathrm{MeOH}$ & 1:1.8:1.2 & 150 & 30 & 52 \\
\hline 4 & $\mathrm{EtOH}$ & 1:1.8:1.2 & 150 & 25 & 55 \\
\hline 5 & AcOEt & 1:1.8:1.2 & 150 & 25 & 21 \\
\hline 6 & $\mathrm{MeOH}$ & $1: 2: 2$ & 150 & 25 & 60 \\
\hline 7 & $\mathrm{MeOH}$ & $1: 1.5: 1.2$ & 150 & 25 & 52 \\
\hline 8 & $\mathrm{MeOH}$ & 1:1.8:1.2 & 140 & 25 & 49 \\
\hline 9 & $\mathrm{MeOH}$ & 1:1.8:1.2 & 160 & 25 & 35 \\
\hline
\end{tabular}

With the optimized conditions in hand, the scope of our MCR was explored using substrates 3a-I. The one-pot MCR of 5-aminopyrazoles (3a-I), with triethyl orthoformate and cyanamide proceeded efficiently with the formation of the desired 4-aminopyrazolo[1,5a] $[1,3,5]$ triazines 4 in high purity and similar yields (Table 2). The reaction was found to be highly chemo- and regioselective affording 1,3,5-triazine ring annulation onto 5aminopyrazole 3a-I. No products of reactions involving a potential nucleophilic attack of the C-4 pyrazole carbon atom or the secondary amino group were detected. The regioisomeric 
2-aminopyrazolo[1,5-a][1,3,5]triazines 6 with an alternative position of the primary amino group were not found in the reaction mixture.

Table 2. Microwave-assisted synthesis of 8-amino-substituted 5-aza-9-deaza-adenines (4)<smiles>[R]Nc1cc([NH2+][CH2+])n2nc(N[R9])cc2n1</smiles>

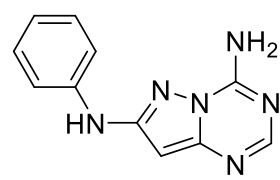

$4 a, 60 \%$

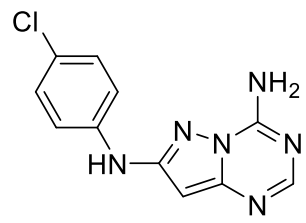

4d, $58 \%$<smiles>Cc1ccc(Nc2cc3ncnc(N)n3n2)cc1</smiles>

$4 \mathrm{~g}, 65 \%$<smiles>Nc1ncnc2cc(Nc3ccc(OC(F)(F)F)cc3)nn12</smiles>

$4 \mathrm{j}, 43 \%$

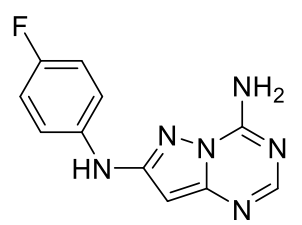

4b, $66 \%$<smiles>Nc1ncnc2cc(Nc3cccc(I)c3)nn12</smiles>

4e, $73 \%$<smiles>COc1ccccc1Nc1cc2ncnc(N)n2n1</smiles>

4h, $75 \%$<smiles>CC(C)c1ccc(Nc2cc3ncnc(N)n3n2)cc1</smiles>

$4 \mathbf{k}, 52 \%$<smiles>Nc1ncnc2cc(Nc3cccc(Cl)c3)nn12</smiles>

4c, $58 \%$<smiles>Cc1cccc(Nc2cc3ncnc(N)n3n2)c1</smiles>

4f, $76 \%$<smiles>COc1ccc(Nc2cc3ncnc(N)n3n2)cc1</smiles>

4i, $79 \%$

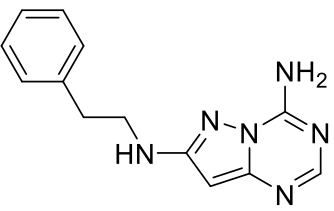

4I, $62 \%$

\footnotetext{
a The reaction was performed using a Discover SP CEM microwave synthesizer with $1 \mathrm{mmol}$ of 5-amino-3-phenylaminopyrazoles (3), $1.8 \mathrm{mmol}$ of triethyl orthoformate and $1.2 \mathrm{mmol}$ of cyanamide at $150{ }^{\circ} \mathrm{C}$ for $25 \mathrm{~min}$ in $2 \mathrm{~mL}$ of $\mathrm{MeOH}$.
} 


\subsection{Restricted rotation around the primary amino group of 5-aza-9-deaza-adenines}

Similarly to the previously reported 5 -aza-9-deaza-adenine analogues, ${ }^{9}$ the primary amino group of the prepared compounds $\mathbf{4}$ was observed to possess a hindered rotation around the $\mathrm{C}-\mathrm{N}$ bond due to the delocalization of electrons over the electron-deficient triazine ring. This restricted rotation made the protons on the amino group magnetically non-equivalent resulting in the appearance of two broad signals at $7.51-8.04 \mathrm{ppm}$ and $8.38-8.56 \mathrm{ppm}$ in the ${ }^{1} \mathrm{H}$ NMR spectra. The signals were found to coalesce at higher temperature (Fig. 2).

The dynamic NMR experiments for $\mathbf{4 a}$ were performed to assess the restricted rotation parameters. The activation enthalpy $\left(\Delta \mathrm{H}^{\ddagger}\right)$ and entropy $\left(\Delta \mathrm{S}^{\ddagger}\right)$ were calculated using the rate constant values estimated via the line-shape analysis of the spectra. The $\Delta \mathrm{H}^{\ddagger}$ and $\Delta \mathrm{S}^{\ddagger}$ values calculated using Eyring equation were $3.89 \mathrm{~kJ} \mathrm{~mol}^{-1}$ and $-180.2 \mathrm{~J} \mathrm{~K}^{-1} \mathrm{~mol}^{-1}$, respectively.

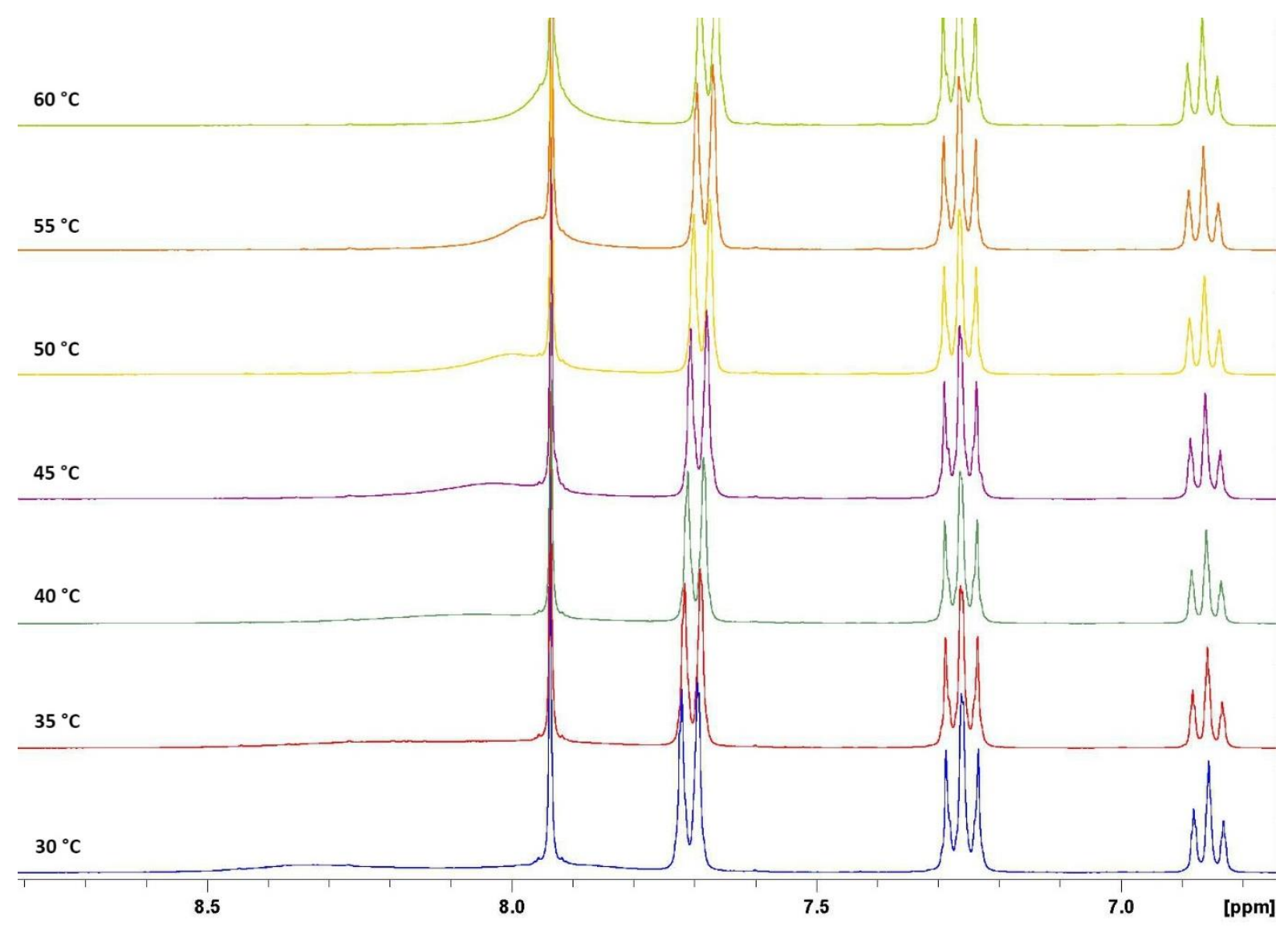

Figure 2. ${ }^{1} \mathrm{H}$ NMR spectra of $4 \mathrm{a}$ in DMSO- $d_{6}$ at range of temperatures. 


\subsection{X-ray crystallography of 4-aminopyrazolo[1,5-a][1,3,5]triazine 4I}

The crystallographic asymmetric unit comprises two independent molecules with the molecular structure of first of these shown in Fig. 3(a) and the second in ESI Fig. $\mathrm{S2}^{\dagger}$. The pyrazolo[1,5-a][1,3,5]triazine ring is effectively planar with the r.m.s. deviation for the nine fitted atoms being $0.0203 \AA$ [0.0234 $\AA$ for the second independent molecule]; the maximum deviation from the least-squares plane of $0.0306(14) \AA$ was found for the $\mathrm{C} 8$ atom [0.0361(14) Å for atom C8a]. The appended primary-N4 and secondary-N7 amine atoms lie $0.0765(24)$ and $0.0632(22) \AA$ to either side of the plane $[0.0364(25)$ and $0.0539(22) \AA]$. With a N7-C71-C72-C73 torsion angle of $-61.11(2)^{\circ}\left[-62.4(2)^{\circ}\right]$, the ethylene group linking the amine-N7 and phenyl ring has a -syn-clinal conformation. The major difference between the two independent molecules relates to the relative orientation of the pendent aromatic residues as seen in the values of the C71-C72-C73-C74 torsion angles of 104.0(2) cf. $115.8(2)^{\circ}$, Fig. 3(b), nevertheless the dihedral angles between the planes of $88.93(4) c f$. $89.17(4)^{\circ}$ are similar and indicate an orthogonal relationship.

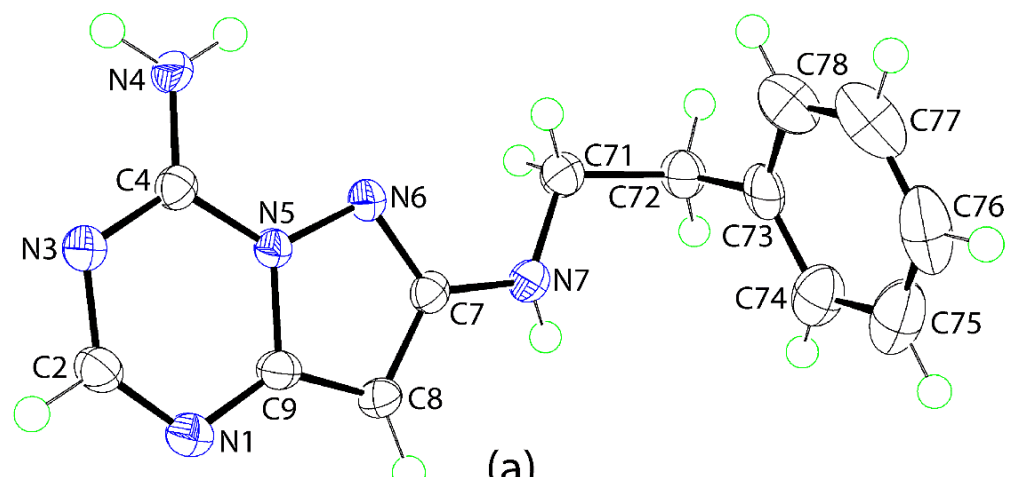

(a)

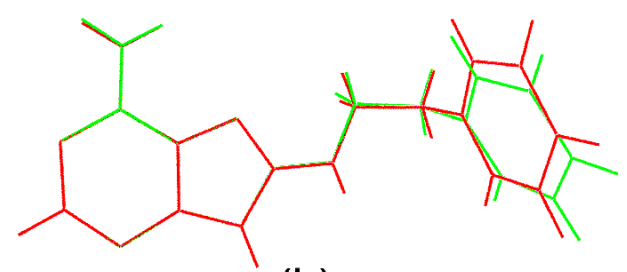

(b)

Figure 3. (a) Molecular structure of $\mathbf{4 I}$ showing atom labelling scheme and $70 \%$ anisotropic displacement parameters and (b) an overlay diagram of the two independent molecules comprising the asymmetric unit: red image, the molecule shown in (a) and green image, molecule "a". The molecules are overlapped so that the triazine rings are coincident. 
As expected from the molecular structure of $4 \mathbf{l}$, there is significant $\mathrm{N}-\mathrm{H} \cdots \mathrm{N}$ hydrogen bonding operating in the crystal; each of the independent molecules engages in analogous hydrogen bonding. Thus, supramolecular ribbons with a corrugated topology are formed along the $c$-axis comprising one type of molecule only, as illustrated for the first independent molecule in Fig. 4; the geometric characteristics of the hydrogen bonding are given in ESI Table $\mathrm{S2}^{+}$. The hydrogen bonding involves the primary amine-N4-H hydrogen atoms functioning as the donors to triazine-N3 and pyrazole-N6 as acceptors to form two different centrosymmetric synthons, being, respectively, eight-membered $\{\cdots \mathrm{HNCN}\}_{2}$ and $10-$ membered $\left\{\cdots \mathrm{HNCN}_{2}\right\}_{2}$. The ribbons stack in layers of like-molecules along the $a$-axis and are offset with respect to each (along the $b$-axis) other allowing their connection into a three-

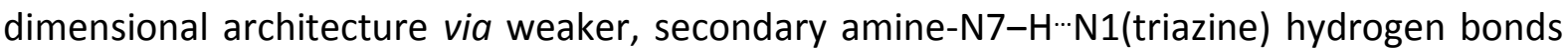
(between unlike molecules). A view of the unit cell contents for $4 \mathrm{I}$ is given in $\mathrm{ESI}$ Fig. $\mathrm{S3}^{\dagger}$.

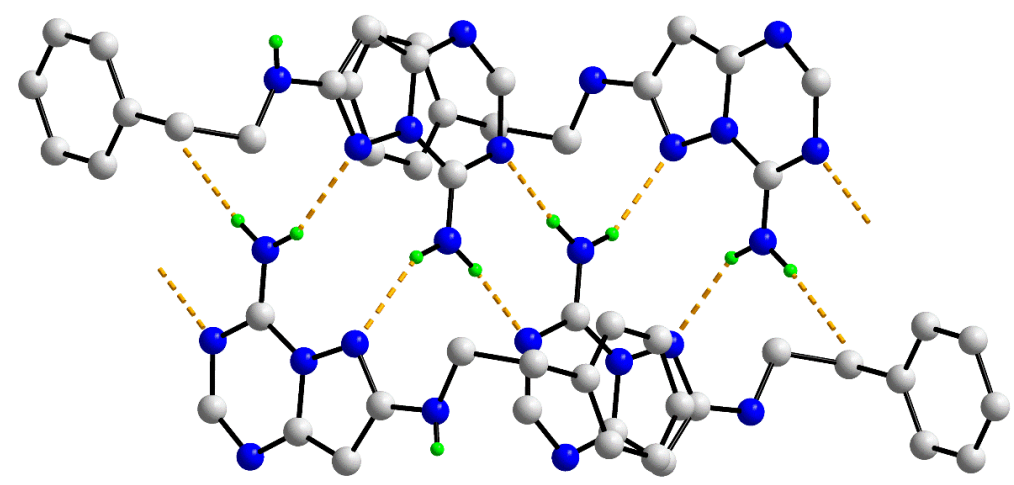

Figure 4. Primary amine-N4-H...N(triazine-N3, pyrazole-N6) hydrogen bonding (see ESI Table $\mathrm{S} 2$ and Fig. $\mathrm{S3}^{+}$) in the crystal of $\mathbf{4 I}$ leading to supramolecular ribbons along the $c$-axis. The $\mathrm{N}-\mathrm{H} \cdots \mathrm{N}$ hydrogen bonding is represented as orange dashed lines, and non-participating hydrogen atoms have been omitted.

\section{Conclusion}

The MCR of 3-amino-substituted 5-aminopyrazoles 3 with cyanamide and triethyl orthoformate proceeded smoothly via a selective 1,3,5-triazine ring closure thus generating a representative library of new 5-aza-9-deaza-adenines 4 . The developed approach is practical and robust and could be attractive for organic and medicinal chemists aiming to 
the preparation of purine-like compounds for the drug discovery process. The method is reproducible in different microwave reactors and under microwave-like heating. The rotation of the primary amino group in $\mathbf{4}$ is restricted and activation parameters for this process are determined using dynamic NMR spectroscopy.

\section{Experimental}

\subsection{General information}

Melting points (uncorrected) were determined on a Stuart ${ }^{\mathrm{TM}} \mathrm{SMP} 40$ automatic melting point apparatus. ${ }^{1} \mathrm{H}$ and ${ }^{13} \mathrm{C}$ NMR spectra were recorded on a Bruker Fourier NMR spectrometer (300 MHz) using DMSO- $d_{6}$ as a solvent and TMS as an internal reference. IR spectra were recorded in $\mathrm{KBr}$ pellets using Varian 640-IR spectrophotometer. Microwave-assisted reactions were carried out in the closed vessel focused single mode using a Discover SP microwave synthesizer (CEM, USA) monitoring reaction temperature by equipped IR sensor. For the method validation, the model reaction was also carried out using Monowave 400 and Monowave 50 (Anton Paar, Austria) reactors.

\subsection{Synthesis of 4-oxo-7-(phenylamino)-3,4-dihydropyrazolo[1,5-a][1,3,5]triazine-8-} carboxylate (2) from 4-aminopyrazolo[1,5-a][1,3,5]triazine-8-carboxylate (1)

An ethyl 4-amino-7-phenylaminopyrazolo[1,5-a][1,3,5]triazine-8-carboxylate (1) 0.335 $\mathrm{mmol}, 100 \mathrm{mg})$ in aqueous $2 \mathrm{M} \mathrm{HCl}(2.0 \mathrm{~mL})$ was irradiated in a $10 \mathrm{~mL}$ seamless pressure vial using microwave system operating at maximal microwave power up to $150 \mathrm{~W}$ (Discover SP, CEM) at $150{ }^{\circ} \mathrm{C}$ for $4 \mathrm{~min}$. After cooling, the precipitated product 2 was filtered and washed with cold water. An analytical sample was recrystallised from DMF \& $\mathrm{MeOH}$. Yield 36\%; mp 329-331 ${ }^{\circ} \mathrm{C}$ (DMF \& MeOH); ${ }^{1} \mathrm{H}$ NMR (300 MHz, DMSO-d $): \delta 1.33\left(3 \mathrm{H}, \mathrm{t},{ }^{3} \mathrm{~J}=7.1 \mathrm{~Hz}, \mathrm{CH}_{3}\right)$, $4.36\left(2 \mathrm{H}, \mathrm{q}^{3}{ }^{3} \mathrm{~J}=7.1 \mathrm{~Hz}, \mathrm{CH}_{2}\right), 6.98\left(1 \mathrm{H}, \mathrm{t},{ }^{3} \mathrm{~J}=7.4 \mathrm{~Hz}, \mathrm{H}-4^{\prime}\right), 7.35\left(2 \mathrm{H}, \mathrm{t},{ }^{3} \mathrm{~J}=8.0 \mathrm{~Hz}, \mathrm{H}-3^{\prime}\right.$ and H$\left.5^{\prime}\right), 7.74\left(2 \mathrm{H}, \mathrm{d},{ }^{3} \mathrm{~J}=7.7 \mathrm{~Hz}, \mathrm{H}-2^{\prime}\right.$ and $\left.\mathrm{H}-6^{\prime}\right), 8.24(1 \mathrm{H}, \mathrm{s}, \mathrm{H}-2), 8.74(1 \mathrm{H}, \mathrm{s}, \mathrm{NH}), 13.04(1 \mathrm{H}, \mathrm{br} \mathrm{s}$, $\mathrm{NH}) ;{ }^{13} \mathrm{C}$ NMR (75 MHz, DMSO- $\left.d_{6}\right): \delta 14.2\left(\mathrm{CH}_{3}\right), 60.1\left(\mathrm{CH}_{2}\right), 90.6$ (C-8), 117.4 (C-2' and C-6'), 121.2 (C-4'), 128.9 (C-3' and C-5'), 140.0 (C-1'), 142.7 (C-8a), 148.7 (C-2), 149.7 (C-4), 154.8 
(C-7), 163.8 (C=O). Anal. calcd. for $\mathrm{C}_{14} \mathrm{H}_{13} \mathrm{~N}_{5} \mathrm{O}_{3}$ : $\mathrm{C}, 56.2 ; \mathrm{H}, 4.4 ; \mathrm{N}, 23.4$. Found: $\mathrm{C}, 55.8 ; \mathrm{H}, 4.5$; N, 23.2.

4.3 Synthesis of 5-amino-3-phenylaminopyrazole (3a) from ethyl 4-amino-7phenylaminopyrazolo[1,5-a][1,3,5]triazine-8-carboxylate (1b)

An ethyl 4-amino-7-phenylaminopyrazolo[1,5-a][1,3,5]triazine-8-carboxylate (1b) 0.335 $\mathrm{mmol}, 100 \mathrm{mg})$ in aqueous $2 \mathrm{M} \mathrm{NaOH}(2.0 \mathrm{~mL})$ was irradiated in a $10 \mathrm{~mL}$ seamless pressure vial using microwave system operating at maximal microwave power up to $150 \mathrm{~W}$ (Discover $\mathrm{SP}, \mathrm{CEM}$ ) at $150{ }^{\circ} \mathrm{C}$ for $4 \mathrm{~min}$. After cooling, the precipitated product 3a was filtered and washed with cold water. An analytical sample was recrystallised from $\mathrm{MeOH}$ to give the product identical to the one obtained according to the earlier described method. ${ }^{12}$ Yield $52 \%$; mp $166-168^{\circ} \mathrm{C}(\mathrm{MeOH})$.

\subsection{General method for the microwave-assisted synthesis of 5-aza-9-deaza-adenines 4}

A mixture of 3-amino-substituted 5-aminopyrazoles 5 (1.0 mmol), cyanamide $(50.4 \mathrm{mg}, 1.20$ $\mathrm{mmol})$ and triethyl orthoformate $(0.30 \mathrm{~mL}, 1.8 \mathrm{mmol})$ in $\mathrm{MeOH}(2.0 \mathrm{~mL})$ was irradiated in a $10 \mathrm{~mL}$ seamless pressure vial using microwave system operating at maximal microwave power up to $150 \mathrm{~W}$ (Discover SP, CEM) or $850 \mathrm{~W}$ (Monowave 450 , Anton Paar) at $150{ }^{\circ} \mathrm{C}$ for 25 min. After cooling, the precipitated product 4 was filtered and washed with cold $\mathrm{MeOH}$ and recrystallised from a suitable solvent.

\subsubsection{4-Amino-7-(phenylamino)pyrazolo[1,5-a][1,3,5]triazine (4a)}

Yield 60\%; mp 277-278 ${ }^{\circ} \mathrm{C}$ (EtOH); ${ }^{1} \mathrm{H}$ NMR (300 MHz, DMSO- $\left.d_{6}\right): \delta 5.80(1 \mathrm{H}, \mathrm{s}, \mathrm{H}-8), 6.86(1 \mathrm{H}$, $\left.t,{ }^{3} \mathrm{~J}=7.3 \mathrm{~Hz}, \mathrm{H}-4^{\prime}\right), 7.26\left(2 \mathrm{H}, \mathrm{t},{ }^{3} \mathrm{~J}=8.0 \mathrm{~Hz}, \mathrm{H}-3^{\prime}\right.$ and $\left.\mathrm{H}-5^{\prime}\right), 7.71\left(2 \mathrm{H}, \mathrm{d},{ }^{3} \mathrm{~J}=7.7 \mathrm{~Hz}, \mathrm{H}-2^{\prime}\right.$ and $\mathrm{H}-$ 6'), $7.89(1 \mathrm{H}, \mathrm{br} \mathrm{s}, \mathrm{NH}), 7.93(1 \mathrm{H}, \mathrm{s}, \mathrm{H}-2), 8.38(1 \mathrm{H}, \mathrm{br} \mathrm{s}, \mathrm{NH}), 9.16(1 \mathrm{H}, \mathrm{s}, \mathrm{NH}) ;{ }^{13} \mathrm{C}$ NMR $(75$ MHz, DMSO- $d_{6}$ ): $\delta 82.5$ (C-8), 116.5 (C-2' and C-6'), 119.5 (C-4'), 128.7 (C-3' and C-5'), 141.7 (C-1'), 148.4 (C-8a), 149.6 (C-4), 154.1 (C-7), 156 (C-2). IR (KBr): v 3467 (N-H), 3305 (N-H), 3245 (N-H), 3053 (C-H), 1637, 1557, 1491, 1373, 1267, $906 \mathrm{~cm}^{-1}$. Anal. calcd. for $\mathrm{C}_{11} \mathrm{H}_{10} \mathrm{~N}_{6}$ : C, 58.4; H, 4.5; N, 37.15. Found: C, 58.2; H, 4.6; N, 37.0. 
Yield 66\%; mp 278-280 ${ }^{\circ} \mathrm{C}(\mathrm{EtOH}) ;{ }^{1} \mathrm{H}$ NMR (300 MHz, DMSO- $\left.d_{6}\right): \delta 5.78(1 \mathrm{H}, \mathrm{s}, \mathrm{H}-8), 7.07$ (2H, $\mathrm{dd},{ }^{3} \mathrm{~J}=8.9 \mathrm{~Hz},{ }^{3} J_{\mathrm{HF}}=8.9 \mathrm{~Hz} \mathrm{H}-3^{\prime}$ and $\left.\mathrm{H}-5^{\prime}\right), 7.74\left(2 \mathrm{H}, \mathrm{dd},{ }^{3} \mathrm{~J}=9.2 \mathrm{~Hz},{ }^{4} J_{\mathrm{HF}}=4.8 \mathrm{~Hz}, \mathrm{H}-2^{\prime}\right.$ and H$\left.6^{\prime}\right), 7.93(1 \mathrm{H}, \mathrm{s}, \mathrm{H}-2), 7.95(1 \mathrm{H}, \mathrm{br} \mathrm{s}, \mathrm{NH}), 8.39(1 \mathrm{H}, \mathrm{br} \mathrm{s}, \mathrm{NH}), 9.20(1 \mathrm{H}, \mathrm{s}, \mathrm{NH}) ;{ }^{13} \mathrm{C}$ NMR $(75$ MHz, DMSO-d $\left.d_{6}\right): \delta 82.3(\mathrm{C}-8), 115.0\left(\mathrm{~d},{ }^{2} J_{C F}=21.6 \mathrm{~Hz}, \mathrm{C}-3^{\prime}\right.$ and $\left.\mathrm{C}-5^{\prime}\right), 117.8\left(\mathrm{~d},{ }^{3} J_{C F}=7.5 \mathrm{~Hz}, \mathrm{C}-\right.$ $2^{\prime}$ and C-6'), 138.3 (d, $\left.{ }^{4} J_{C F}=2.2 \mathrm{~Hz}, C^{\prime}-1^{\prime}\right), 148.4$ (C-8a), 149.6 (C-4), 154.2 (C-7), 156.0 (d, ${ }^{1} J_{C F}$ $\left.=235.8 \mathrm{~Hz}, \mathrm{C}-4^{\prime}\right), 156.0(\mathrm{C}-2)$. IR (KBr): v $3469(\mathrm{~N}-\mathrm{H}), 3310(\mathrm{~N}-\mathrm{H}), 3234(\mathrm{~N}-\mathrm{H}), 3062(\mathrm{C}-\mathrm{H})$, $1685,1578,1508,1372,1283,1208 \mathrm{~cm}^{-1}$. Anal. calcd. for $\mathrm{C}_{11} \mathrm{H}_{9} \mathrm{FN}_{6}$ : C, 54.1; H, 3.7; N, 34.4 . Found: C, 53.9; H, 3.9; N, 34.15 .

4.5.3 4-Amino-7-[(3-chlorophenyl)amino]pyrazolo[1,5-a][1,3,5]triazine (4c)

Yield 58\%; mp 261-263 ${ }^{\circ} \mathrm{C}$ (EtOH); ${ }^{1} \mathrm{H}$ NMR (300 MHz, DMSO- $\left.d_{6}\right): \delta 5.82(1 \mathrm{H}, \mathrm{s}, \mathrm{H}-8), 6.88(1 \mathrm{H}$, ddd, $\left.{ }^{4} J=0.8 \mathrm{~Hz},{ }^{4} J=2.0 \mathrm{~Hz},{ }^{3} J=7.9 \mathrm{~Hz}, \mathrm{H}^{\prime} 4^{\prime}\right), 7.27\left(1 \mathrm{H}, \mathrm{t},{ }^{3} \mathrm{~J}=8.1 \mathrm{~Hz}, \mathrm{H}-5^{\prime}\right), 7.64\left(1 \mathrm{H}, \mathrm{t},{ }^{4} J=2.1\right.$ $\left.\mathrm{Hz}, \mathrm{H}-2^{\prime}\right), 7.76\left(1 \mathrm{H}, \mathrm{ddd},{ }^{4} J=0.8 \mathrm{~Hz},{ }^{4} J=2.1 \mathrm{~Hz},{ }^{3} \mathrm{~J}=8.3 \mathrm{~Hz}, \mathrm{H}-6^{\prime}\right), 7.95(1 \mathrm{H}, \mathrm{s}, \mathrm{H}-2), 8.04(1 \mathrm{H}$, br s, NH), $8.42\left(1 \mathrm{H}\right.$, br s, NH), $9.39(1 \mathrm{H}, \mathrm{s}, \mathrm{NH}) ;{ }^{13} \mathrm{C}$ NMR $\left(75 \mathrm{MHz}, \mathrm{DMSO}-d_{6}\right): \delta 82.8$ (C-8), 115.1 (C-6'), 115.6 (C-2'), 119.2 (C-4'), 130.4 (C-5'), 133.2 (C-3'), 143.1 (C-1'), 148.5 (C-8a), 149.7 (C-4), 154.2 (C-7), 155.4 (C-2). IR (KBr): v 3443 (N-H), 3304 (N-H), 3053 (C-H), 1680, $1619,1591,1558,1447,1371,1271 \mathrm{~cm}^{-1}$. Anal. calcd. for $\mathrm{C}_{11} \mathrm{H}_{9} \mathrm{ClN}_{6}$ : C, 50.7; H, 3.5; N, 32.2 . Found: C, 50.5; H, 3.55; N, 32.1 .

\subsubsection{4-Amino-7-[(4-chlorophenyl)amino]pyrazolo[1,5-a][1,3,5]triazine (4d)}

Yield 58\%; mp 283-285 ${ }^{\circ} \mathrm{C}$ (EtOH); ${ }^{1} \mathrm{H}$ NMR (300 MHz, DMSO- $\left.d_{6}\right): \delta 5.79$ (1H, s, H-8), 7.26 (2H, $\mathrm{d}^{3}{ }^{3} \mathrm{~J}=8.9 \mathrm{~Hz}, \mathrm{H}-3^{\prime}$ and $\left.\mathrm{H}-5^{\prime}\right), 7.76\left(2 \mathrm{H}, \mathrm{d}^{3}{ }^{3} \mathrm{~J}=9.0 \mathrm{~Hz}, \mathrm{H}-2^{\prime}\right.$ and $\left.\mathrm{H}-6^{\prime}\right), 7.94(1 \mathrm{H}, \mathrm{s}, \mathrm{H}-2), 7.99$ $\left(1 \mathrm{H}\right.$, br s, NH), $8.43\left(1 \mathrm{H}\right.$, br s, NH), $9.35(1 \mathrm{H}, \mathrm{s}, \mathrm{NH}) ;{ }^{13} \mathrm{C}$ NMR $\left(75 \mathrm{MHz}, \mathrm{DMSO}-d_{6}\right): \delta 82.6$ (C8), 118.1 (C-2' and C-6'), 122.9 (C-4'), 128.4 (C-3' and C-5'), 140.6 (C-1'), 148.4 (C-8a), 149.7 (C-4), 154.2 (C-7), 155.6 (C-2). IR (KBr): v 3634 (N-H), $3445(\mathrm{~N}-\mathrm{H}), 3307(\mathrm{~N}-\mathrm{H}), 3092$ (C-H), $1680,1593,1559,1443,1373,1249 \mathrm{~cm}^{-1}$. Anal. calcd. for $\mathrm{C}_{11} \mathrm{H}_{9} \mathrm{ClN}_{6}$ : C, 50.7; H, 3.5; N, 32.2 . Found: $\mathrm{C}, 50.5 ; \mathrm{H}, 3.6 ; \mathrm{N}, 32.0$.

\subsubsection{4-Amino-7-[(3-iodophenyl)amino]pyrazolo[1,5-a][1,3,5]triazine (4e)}

Yield 73\%; mp 246-248 ${ }^{\circ} \mathrm{C}$ (EtOH); ${ }^{1} \mathrm{H}$ NMR (300 MHz, DMSO- $\left.d_{6}\right): \delta 5.81(1 \mathrm{H}, \mathrm{s}, \mathrm{H}-8), 7.06(1 \mathrm{H}$, $\left.t,{ }^{3} J=8.0 \mathrm{~Hz}, \mathrm{H}-5^{\prime}\right), 7.20\left(1 \mathrm{H}, \mathrm{ddd},{ }^{4} J=1.0 \mathrm{~Hz},{ }^{4} J=1.4 \mathrm{~Hz},{ }^{3} \mathrm{~J}=7.8 \mathrm{~Hz}, \mathrm{H}-4^{\prime}\right), 7.74\left(1 \mathrm{H}, \mathrm{t}^{4}{ }^{4} \mathrm{~J}=1.9\right.$ 
$\left.\mathrm{Hz}, \mathrm{H}-2^{\prime}\right), 7.95(1 \mathrm{H}, \mathrm{s}, \mathrm{H}-2), 7.98(1 \mathrm{H}, \mathrm{br} \mathrm{s}, \mathrm{NH}), 8.02\left(1 \mathrm{H}, \mathrm{ddd},{ }^{4} \mathrm{~J}=0.8 \mathrm{~Hz},{ }^{4} \mathrm{~J}=2.2 \mathrm{~Hz},{ }^{3} \mathrm{~J}=8.3\right.$ $\left.\mathrm{Hz}, \mathrm{H}-6^{\prime}\right), 8.41(1 \mathrm{H}, \mathrm{br} \mathrm{s}, \mathrm{NH}), 9.29(1 \mathrm{H}, \mathrm{s}, \mathrm{NH}) ;{ }^{13} \mathrm{C}$ NMR $\left(75 \mathrm{MHz}, \mathrm{DMSO}-d_{6}\right): \delta 82.8$ (C-8), 94.5 (C-3'), 115.8 (C-6'), 124.2 (C-2'), 128.1 (C-4'), 130.9 (C-5'), 143.2 (C-1'), 148.5 (C-8a), 149.7 (C-4), 154.2 (C-7), 155.4 (C-2). IR (KBr): v 3377 (N-H), 3300 (N-H), 3242 (N-H), 3059 (C$\mathrm{H}), 1658,1544,1491,1370,1275,1231 \mathrm{~cm}^{-1}$. Anal. calcd. for $\mathrm{C}_{11} \mathrm{H}_{9} \mathrm{IN}_{6}$ : C, 37.5; $\mathrm{H}, 2.6 ; \mathrm{N}$, 23.9. Found: $\mathrm{C}, 37.3 ; \mathrm{H}, 2.7 ; \mathrm{N}, 23.7$.

\subsubsection{4-Amino-7-[(3-methylphenyl)amino]pyrazolo[1,5-a][1,3,5]triazine (4f)}

Yield 76\%; mp 223-225 ${ }^{\circ} \mathrm{C}$ (EtOH); ${ }^{1} \mathrm{H}$ NMR (300 MHz, DMSO-d $): \delta 2.31\left(3 \mathrm{H}, \mathrm{s}, \mathrm{CH}_{3}\right), 5.79$ $(1 \mathrm{H}, \mathrm{s}, \mathrm{H}-8), 6.67\left(1 \mathrm{H}, \mathrm{d},{ }^{3} \mathrm{~J}=7.5 \mathrm{~Hz}, \mathrm{H}-4^{\prime}\right), 7.14\left(1 \mathrm{H}, \mathrm{t},{ }^{3} \mathrm{~J}=7.8 \mathrm{~Hz}, \mathrm{H}-5^{\prime}\right), 7.42\left(1 \mathrm{H}, \mathrm{s}, \mathrm{H}-2^{\prime}\right)$, $7.54\left(1 \mathrm{H}, \mathrm{d}, 3^{3} \mathrm{~J}=8.3 \mathrm{~Hz}, \mathrm{H}-6^{\prime}\right), 7.88(1 \mathrm{H}, \mathrm{br} \mathrm{s}, \mathrm{NH}), 7.92(1 \mathrm{H}, \mathrm{s}, \mathrm{H}-2), 8.38(1 \mathrm{H}, \mathrm{br} \mathrm{s}, \mathrm{NH}), 9.06$ $(1 \mathrm{H}, \mathrm{s}, \mathrm{NH}) ;{ }^{13} \mathrm{C}$ NMR (75 MHz, DMSO-d 6 ): $\delta 21.2\left(\mathrm{CH}_{3}\right), 82.6$ (C-8), 113.8 (C-6'), $116.9\left(\mathrm{C}-2^{\prime}\right)$, 120.4 (C-4'), 128.6 (C-5'), 137.8 (C-3'), 141.6 (C-1'), 148.4 (C-8a), 149.6 (C-4), 154.0 (C-7), 156.1 (C-2). IR (KBr): v $3466(\mathrm{~N}-\mathrm{H}), 3286(\mathrm{~N}-\mathrm{H}), 3140(\mathrm{~N}-\mathrm{H}), 3107$ (C-H), 1654, 1562, 1499, $1368,1327,1279 \mathrm{~cm}^{-1}$. Anal. calcd. for $\mathrm{C}_{12} \mathrm{H}_{12} \mathrm{~N}_{6}$ : $\mathrm{C}, 60.0 ; \mathrm{H}, 5.0 ; \mathrm{N}, 35.0$. Found: $\mathrm{C}, 59.7 ; \mathrm{H}$, $5.2 ; N, 34.8$.

\subsubsection{4-Amino-7-[(4-methylphenyl)amino]pyrazolo[1,5-a][1,3,5]triazine (4g)}

Yield 65\%; mp 270-272 ${ }^{\circ} \mathrm{C}$ (EtOH); ${ }^{1} \mathrm{H}$ NMR (300 MHz, DMSO-d $\left.d_{6}\right): \delta 2.24\left(3 \mathrm{H}, \mathrm{s}, \mathrm{CH}_{3}\right), 5.76$ $(1 \mathrm{H}, \mathrm{s}, \mathrm{H}-8), 7.06\left(2 \mathrm{H}, \mathrm{d}^{3}{ }^{3} \mathrm{~J}=8.1 \mathrm{~Hz}, \mathrm{H}-3^{\prime}\right.$ and $\left.\mathrm{H}-5^{\prime}\right), 7.59\left(2 \mathrm{H}, \mathrm{d},{ }^{3} \mathrm{~J}=8.5 \mathrm{~Hz}, \mathrm{H}-2^{\prime}\right.$ and $\left.\mathrm{H}-6^{\prime}\right)$, $7.83(1 \mathrm{H}, \mathrm{br} \mathrm{s}, \mathrm{NH}), 7.91(1 \mathrm{H}, \mathrm{s}, \mathrm{H}-2), 8.36(1 \mathrm{H}, \mathrm{br} \mathrm{s}, \mathrm{NH}), 9.03(1 \mathrm{H}, \mathrm{s}, \mathrm{NH}) ;{ }^{13} \mathrm{C} \mathrm{NMR}(75 \mathrm{MHz}$, DMSO- $\left.d_{6}\right): \delta 20.2\left(\mathrm{CH}_{3}\right), 82.3$ (C-8), 116.6 (C-2' and C-6'), 128.1 (C-4'), 129.1 (C-3' and C-5'), 139.3 (C-1'), 148.4 (C-8a), 149.6 (C-4), 154.0 (C-7), 156.2 (C-2). IR (KBr): v 3462 (N-H), 3286 $(\mathrm{N}-\mathrm{H}), 3029$ (C-H), 1659, 1554, 1495, 1372, 1332, $1269 \mathrm{~cm}^{-1}$. Anal. calcd. for $\mathrm{C}_{12} \mathrm{H}_{12} \mathrm{~N}_{6}$ : C, $60.0 ; H, 5.0 ; N, 35.0$. Found: $C, 59.8 ; H, 5.2 ; N, 34.8$.

\subsubsection{4-Amino-7-[(2-methoxyphenyl)amino]pyrazolo[1,5-a][1,3,5]triazine (4h)}

Yield 75\%; mp 225-227 ${ }^{\circ} \mathrm{C}$ (EtOH); ${ }^{1} \mathrm{H}$ NMR (300 MHz, DMSO-d 6 ): $\delta 3.89$ (3H, s, $\mathrm{OCH}_{3}$ ), 6.09 $(1 \mathrm{H}, \mathrm{s}, \mathrm{H}-8), 6.86\left(1 \mathrm{H}, \mathrm{ddd},{ }^{4} J=1.8 \mathrm{~Hz},{ }^{3} J=7.5 \mathrm{~Hz},{ }^{3} J=7.5 \mathrm{~Hz}, \mathrm{H}-4^{\prime}\right), 6.92\left(1 \mathrm{H}, \mathrm{ddd},{ }^{4} J=1.8 \mathrm{~Hz}\right.$, $\left.{ }^{3} J=7.6 \mathrm{~Hz},{ }^{3} \mathrm{~J}=7.6 \mathrm{~Hz}, \mathrm{H}-5^{\prime}\right), 6.98\left(1 \mathrm{H}, \mathrm{dd},{ }^{4} J=1.7 \mathrm{~Hz},{ }^{3} J=7.7 \mathrm{~Hz}, \mathrm{H}-6^{\prime}\right), 7.00(1 \mathrm{H}, \mathrm{s}, \mathrm{H}-2), 7.91$ $\left(1 \mathrm{H}\right.$, br s, NH), $7.94(1 \mathrm{H}, \mathrm{s}, \mathrm{NH}), 8.36(1 \mathrm{H}, \mathrm{br} \mathrm{s}, \mathrm{NH}), 8.55\left(1 \mathrm{H}, \mathrm{dd},{ }^{4} \mathrm{~J}=1.7 \mathrm{~Hz},{ }^{3} \mathrm{~J}=7.8 \mathrm{~Hz}, \mathrm{H}-3^{\prime}\right)$; ${ }^{13} \mathrm{C}$ NMR (75 MHz, DMSO- $\left.d_{6}\right): \delta 55.6\left(\mathrm{OCH}_{3}\right), 83.7$ (C-8), 110.1 (C-3'), 116.9 (C-6'), 119.8 (C-4') 
120.8 (C-5'), 130.6 (C-1'), 146.9 (C-2'), 148.1 (C-8a), 149.7 (C-4), 154.0 (C-7), 156.1 (C-2). IR (KBr): v 3427 (N-H), 3331 (N-H), 3050 (C-H), 1672, 1598, 1555 1464, 1373, 1312, $1250 \mathrm{~cm}^{-1}$. Anal. calcd. for $\mathrm{C}_{12} \mathrm{H}_{12} \mathrm{~N}_{6} \mathrm{O}: \mathrm{C}, 56.2 ; \mathrm{H}, 4.7 ; \mathrm{N}, 32.8$. Found: $\mathrm{C}, 56.0 ; \mathrm{H}, 4.95 ; \mathrm{N}, 32.5$.

\subsubsection{4-Amino-7-[(4-methoxyphenyl)amino]pyrazolo[1,5-a][1,3,5]triazine (4i)}

Yield 79\%; mp 278-280 ${ }^{\circ} \mathrm{C}(\mathrm{EtOH}) ;{ }^{1} \mathrm{H}$ NMR (300 MHz, DMSO-d 6 ): $\delta 3.72\left(3 \mathrm{H}, \mathrm{s}, \mathrm{OCH}_{3}\right), 5.72$ $(1 \mathrm{H}, \mathrm{s}, \mathrm{H}-8), 6.85\left(2 \mathrm{H}, \mathrm{d}, 3^{3} \mathrm{~J}=9.0 \mathrm{~Hz}, \mathrm{H}-3^{\prime}\right.$ and $\left.\mathrm{H}-5^{\prime}\right), 7.63\left(2 \mathrm{H}, \mathrm{d},{ }^{3} \mathrm{~J}=9.1 \mathrm{~Hz}, \mathrm{H}-2^{\prime}\right.$ and $\left.\mathrm{H}-6^{\prime}\right)$, $7.80(1 \mathrm{H}, \mathrm{br} \mathrm{s}, \mathrm{NH}), 7.90(1 \mathrm{H}, \mathrm{s}, \mathrm{H}-2), 8.36(1 \mathrm{H}, \mathrm{br} \mathrm{s}, \mathrm{NH}), 8.93(1 \mathrm{H}, \mathrm{s}, \mathrm{NH}) ;{ }^{13} \mathrm{C}$ NMR $(75 \mathrm{MHz}$, DMSO- $\left.d_{6}\right): \delta 55.0\left(\mathrm{OCH}_{3}\right), 82.0(\mathrm{C}-8), 114.0\left(\mathrm{C}-3^{\prime}\right.$ and $\left.\mathrm{C}-5^{\prime}\right), 117.9\left(\mathrm{C}-2^{\prime}\right.$ and $\left.\mathrm{C}-6^{\prime}\right), 135.3\left(\mathrm{C}-1^{\prime}\right)$, 148.4 (C-8a), 149.5 (C-4), 152.8 (C-4'), 154.0 (C-7), 156.3 (C-2). IR (KBr): v 3467 (N-H), 3243 (N-H), 3057 (N-H), 3032 (C-H), 1638, 1557, 1493, 1266, 1245, $1034 \mathrm{~cm}^{-1}$. Anal. calcd. for $\mathrm{C}_{12} \mathrm{H}_{12} \mathrm{~N}_{6} \mathrm{O}: \mathrm{C}, 56.2 ; \mathrm{H}, 4.7 ; \mathrm{N}, 32.8$. Found: $\mathrm{C}, 56.1 ; \mathrm{H}, 4.8 ; \mathrm{N}, 32.7$.

\subsubsection{4-Amino-7-[(4-trifluoromethoxyphenyl)amino]pyrazolo[1,5-a][1,3,5]triazine (4j)}

Yield 43\%; mp 241-243 ${ }^{\circ} \mathrm{C}$ (EtOH); ${ }^{1} \mathrm{H}$ NMR (300 MHz, DMSO-d $\left.d_{6}\right): \delta 5.81(1 \mathrm{H}, \mathrm{s}, \mathrm{H}-8), 7.22(2 \mathrm{H}$, d, ${ }^{3} \mathrm{~J}=9.0 \mathrm{~Hz}, \mathrm{H}-3^{\prime}$ and $\left.\mathrm{H}-5^{\prime}\right), 7.83\left(2 \mathrm{H}, \mathrm{d}^{3}{ }^{3} \mathrm{~J}=9.2 \mathrm{~Hz}, \mathrm{H}-2^{\prime}\right.$ and $\left.\mathrm{H}-6^{\prime}\right), 7.95(1 \mathrm{H}, \mathrm{s}, \mathrm{H}-2), 7.97$ $\left(1 \mathrm{H}\right.$, br s, NH), $8.45\left(1 \mathrm{H}\right.$, br s, NH), $9.43(1 \mathrm{H}, \mathrm{s}, \mathrm{NH}) ;{ }^{13} \mathrm{C}$ NMR $\left(75 \mathrm{MHz}, \mathrm{DMSO}-d_{6}\right): \delta 82.6$ (C8), $115.2\left(C-2^{\prime}\right.$ and $\left.C-6^{\prime}\right), 120.2\left(q,{ }^{1} J_{C F}=254.8 \mathrm{~Hz}, C F_{3}\right), 121.6\left(C-3^{\prime}\right.$ and $\left.C-5^{\prime}\right), 140.9\left(q,{ }^{3} J_{C F}=\right.$ $\left.1.9 \mathrm{~Hz}, \mathrm{C}-4^{\prime}\right), 141.0$ (C-1'), 148.4 (C-8a), 149.7 (C-4), 154.2 (C-7), 155.6 (C-2). IR (KBr): v 3467 (N-H), 3307 (N-H), 3249 (N-H), 3067 (C-H), 1639, 1561, 1493, 1320, 1268, $1204 \mathrm{~cm}^{-1}$. Anal. calcd. for $\mathrm{C}_{12} \mathrm{H}_{9} \mathrm{FN}_{6} \mathrm{O}: \mathrm{C}, 46.5 ; \mathrm{H}, 2.9 ; \mathrm{N}, 27.1$. Found: $\mathrm{C}, 46.3 ; \mathrm{H}, 3.15 ; \mathrm{N}, 26.9$.

\subsection{Synthesis of 4-amino-7-[(4-isopropylphenyl)amino]pyrazolo[1,5-a][1,3,5]triazine (4k)}

A mixture of 5-amino-3-(4-isopropylphenyl)aminopyrazole $3 \mathbf{k}$ (216 mg, $1.00 \mathrm{mmol}$ ), cyanamide $(50.4 \mathrm{mg}, 1.20 \mathrm{mmol})$ and triethyl orthoformate $(0.30 \mathrm{~mL}, 1.8 \mathrm{mmol})$ in $\mathrm{MeOH}$ $(2.0 \mathrm{~mL})$ was irradiated in a $10 \mathrm{~mL}$ seamless pressure vial using microwave system operating at maximal microwave power up to $150 \mathrm{~W}$ (Discover SP, CEM) at $150{ }^{\circ} \mathrm{C}$ for $25 \mathrm{~min}$. Product was purified by column chromatography on silica gel using ethyl acetate : hexane (6:4) as an eluent. An analytical sample was recrystallised from $\mathrm{MeOH}$.

Yield 52\%; mp 248-250 ${ }^{\circ} \mathrm{C}(\mathrm{MeOH}) ;{ }^{1} \mathrm{H}$ NMR (300 MHz, DMSO- $\left.d_{6}\right): \delta 1.19\left(6 \mathrm{H}, \mathrm{d},{ }^{3} \mathrm{~J}=7.0 \mathrm{~Hz}\right.$, $\left.\left(\mathrm{CH}_{3}\right)_{2}\right), 2.83\left(1 \mathrm{H}, \mathrm{m},{ }^{3} \mathrm{~J}=6.9 \mathrm{~Hz}, \mathrm{CH}\right), 5.77(1 \mathrm{H}, \mathrm{s}, \mathrm{H}-8), 7.12\left(2 \mathrm{H}, \mathrm{d},{ }^{3} \mathrm{~J}=8.5 \mathrm{~Hz}, \mathrm{H}-3^{\prime}\right.$ and $\left.\mathrm{H}-5^{\prime}\right)$, 
$7.61\left(2 \mathrm{H}, \mathrm{d}^{3}{ }^{3} \mathrm{~J}=8.6 \mathrm{~Hz}, \mathrm{H}-2^{\prime}\right.$ and H-6'), $7.80(1 \mathrm{H}, \mathrm{br} \mathrm{s}, \mathrm{NH}), 7.91(1 \mathrm{H}, \mathrm{s}, \mathrm{H}-2), 8.35(1 \mathrm{H}, \mathrm{br} \mathrm{s}$, $\mathrm{NH}), 9.03(1 \mathrm{H}, \mathrm{s}, \mathrm{NH}) ;{ }^{13} \mathrm{C}$ NMR (75 MHz, DMSO-d 6 ): $\delta 24.0\left(2 \times \mathrm{CH}_{3}\right), 32.6(\mathrm{CH}), 82.4(\mathrm{C}-8)$, 116.6 (C-2' and C-6'), 126.4 (C-3' and C-5'), 139.4 and 139.6 (C-1' and C-4'), 148.4 (C-8a), 149.6 (C-4), 154.0 (C-7), 156.2 (C-2). IR (KBr): v 3466 (N-H), 3246 (N-H), 3057 (N-H), 2959 (C$\mathrm{H}), 1637,1552,1492,1371,1267,1185 \mathrm{~cm}^{-1}$. Anal. calcd. for $\mathrm{C}_{14} \mathrm{H}_{16} \mathrm{~N}_{6}: \mathrm{C}, 62.7 ; \mathrm{H}, 6.0 ; \mathrm{N}$, 31.3. Found: $\mathrm{C}, 62.5 ; \mathrm{H}, 6.2 ; \mathrm{N}, 31.05$.

\subsection{Synthesis of 4-amino-7-(phenethylamino)pyrazolo[1,5-a][1,3,5]triazine (4I)}

A mixture of 5-amino-3-phenylethylaminopyrazole 31 (202 mg, $1.00 \mathrm{mmol}$ ), cyanamide (50.4 $\mathrm{mg}, 1.20 \mathrm{mmol})$ and triethyl orthoformate $(0.30 \mathrm{~mL}, 1.8 \mathrm{mmol})$ in $\mathrm{MeOH}(2.0 \mathrm{~mL})$ was irradiated in a $10 \mathrm{~mL}$ seamless pressure vial using microwave system operating at maximal microwave power up to $150 \mathrm{~W}$ (Discover SP, CEM) at $150{ }^{\circ} \mathrm{C}$ for $25 \mathrm{~min}$. Product was purified by column chromatography on silica gel using ethyl acetate : hexane (6:4) as an eluent. Analytical sample was recrystallised from MeCN.

Yield 62\%; mp 166-168 ${ }^{\circ} \mathrm{C}(\mathrm{MeCN}) ;{ }^{1} \mathrm{H}$ NMR (300 MHz, DMSO- $\left.d_{6}\right): \delta{ }^{1} \mathrm{H}$ NMR (300 MHz, DMSO-d $\left.d_{6}\right): \delta 2.88\left(2 \mathrm{H}, \mathrm{t},{ }^{3} \mathrm{~J}=7.5 \mathrm{~Hz}, \mathrm{CH}_{2}\right), 3.43\left(2 \mathrm{H}, \mathrm{q},{ }^{3} \mathrm{~J}=7.1 \mathrm{~Hz}, \mathrm{CH}_{2}\right), 5.56(1 \mathrm{H}, \mathrm{s}, \mathrm{H}-8), 6.25$ $\left(1 \mathrm{H}, \mathrm{t},{ }^{3} \mathrm{~J}=5.8 \mathrm{~Hz}, \mathrm{NH}\right), 7.17-7.30\left(5 \mathrm{H}, \mathrm{m}, \mathrm{H}-\mathrm{1}^{\prime}, \mathrm{H}-2^{\prime}, \mathrm{H}-3^{\prime}, \mathrm{H}-4^{\prime}\right.$, and $\left.\mathrm{H}-5^{\prime}\right), 7.52(1 \mathrm{H}, \mathrm{br} \mathrm{s}, \mathrm{NH})$, $7.83(1 \mathrm{H}, \mathrm{s}, \mathrm{H}-2), 8.10(1 \mathrm{H}, \mathrm{br} \mathrm{s}, \mathrm{NH}) ;{ }^{13} \mathrm{C}$ NMR $(75 \mathrm{MHz}$, DMSO-d $)$ : $\delta 35.3\left(\mathrm{CH}_{2}\right), 44.4\left(\mathrm{CH}_{2}\right)$, 80.4 (C-8), 125.9 (C-4'), 128.2 (C-2' and C-6'), 128.7 (C-3' and C-5'), 139.8 (C-1'), 149.3 (C-8a and C-4), 153.5 (C-7), 160.5 (C-2). IR (KBr): v $3306(\mathrm{~N}-\mathrm{H}), 3023(\mathrm{~N}-\mathrm{H}), 2923(\mathrm{C}-\mathrm{H})$, 1680, 1564, 1487, 1379, 1321, 1266, $1009 \mathrm{~cm}^{-1}$. Anal. calcd. for $\mathrm{C}_{13} \mathrm{H}_{14} \mathrm{~N}_{6}$ : C, 61.4; H, 5.55; N, 33.05 . Found: C, 61.2; H, 5.8; N, 32.8.

\subsection{Dynamic NMR analysis}

Dynamic NMR experiments and lineshape analysis for 4a were conducted on a Bruker Fourier spectrometer $(300 \mathrm{MHz})$ using $\mathrm{DMSO}^{-d_{6}}$ as a solvent and TMS as an internal reference at a temperature range of $27-60^{\circ} \mathrm{C}$. A temperature below the coalescence point $\left(27^{\circ} \mathrm{C}\right.$ ) was chosen to fix parameters for the dynamic experiments (Fix Line Broadening at $0.4 \mathrm{~Hz}$ ). Reaction rate parameters of exchange process at $30-60^{\circ} \mathrm{C}$ were obtained using the 
DNMR Lineshape Fitting module ${ }^{13}$ and plotting a graph of $\ln (k / T)$ vs $1 / T$. The activation parameters for the rotation around the $\mathrm{C}-\mathrm{NH}_{2}$ bond were calculated using the Eyring equation.

\subsection{X-ray crystallographic analysis}

Intensity data for crystals $(0.03 \times 0.09 \times 0.13 \mathrm{~mm})$ of $4 \mathrm{l}$ were measured at $100 \mathrm{~K}$ on an Rigaku/Oxford Diffraction XtaLAB Synergy diffractometer (Dualflex, AtlasS2) fitted with CuK $\alpha$ radiation $\left(\lambda=1.54178 \AA\right.$ ) so that $\theta_{\max }=67.1^{\circ}$. Data reduction and Gaussian absorption corrections were by standard methods. ${ }^{14}$ The structures were solved by direct methods ${ }^{15}$ and refined ${ }^{16}$ on $F^{2}$ with anisotropic displacement parameters and $\mathrm{C}$-bound $\mathrm{H}$ atoms included in the riding model approximation. The $\mathrm{N}$-bound $\mathrm{H}$ atoms were refined freely. $\mathrm{A}$ weighting scheme of the form $\mathrm{w}=1 /\left[\sigma^{2}\left(F_{\mathrm{o}}^{2}\right)+(a P)^{2}+b P\right]$ where $\left.P=\left(F_{\mathrm{o}}^{2}+2 F_{\mathrm{c}}^{2}\right) / 3\right)$ was introduced in each case. The molecular structure diagrams showing $70 \%$ probability displacement ellipsoids were generated by ORTEP for Windows ${ }^{17}$ and the packing diagrams with DIAMOND. ${ }^{18}$ Additional data analysis was made with PLATON. ${ }^{19}$

4.9.1 Crystal data for 4I: $\mathrm{C}_{13} \mathrm{H}_{14} \mathrm{~N}_{6}, M=254.30$, monoclinic, $P 2 / c, a=21.6171(4), b=$ 9.5233(2), $c=12.2819(2) \AA, \beta=104.881(2)^{\circ}, V=2443.63(8) \AA^{3}, Z=8, D_{x}=1.382 \mathrm{~g} \mathrm{~cm}^{-3}$, $F(000)=1072, \mu=0.725 \mathrm{~mm}^{-1}$, no. reflns meas. $=29918$, no. unique reflns $=4377\left(R_{\text {int }}=\right.$ 0.037 ), no. reflns with $I \geq 2 \sigma(I)=4112$, no. parameters $=367, R$ (obs. data) $=0.048$, $a$ and $b$ in weighting scheme $=0.057$ and 2.237, $w R 2$ (all data) $=0.130$. CCDC deposition number: 1866663.

\section{Acknowledgements}

The Research Centre for Crystalline Materials (Sunway University) is thanked for the X-ray intensity data. This work is supported by the Ministry of Higher Education, Malaysia under Fundamental Research Grant Scheme, grant number FRGS/1/2015/SG01/MUSM/03/1.

\section{Appendix A. Supplementary data}

+ Supplementary data associated with this article can be found in the online version, at https://doi.org/10.1016/j.tet.XXXX.XX.XXXX 


\section{References}

1. Lim, F. P. L.; Tan, L. Y.; Tiekink, E. R. T.; Dolzhenko, A. V., A one-pot, multicomponent reaction for the synthesis of novel 2-alkyl substituted 4-aminoimidazo[1,2-a][1,3,5]triazines. RSC Adv. 2018, 8 (38), 21495-21504.

2. Burnstock, G.; Verkhratsky, A., Evolutionary origins of the purinergic signalling system. Acta Physiol. 2009, 195 (4), 415-447.

3. Lim, F. P. L.; Dolzhenko, A. V., 1,3,5-Triazine-based analogues of purine: From isosteres to privileged scaffolds in medicinal chemistry. Eur. J. Med. Chem. 2014, 85, 371-390.

4. Hutterer, C.; Milbradt, J.; Korn, K.; Zeittrager, I.; Bahsi, H.; Wagner, S.; Marschall, M.; Eickhoff, J.; Zischinsky, G.; Wolf, A.; Degenhart, C.; Unger, A.; Baumann, M.; Klebl, B., A novel CDK7 inhibitor of the Pyrazolotriazine class exerts broad-spectrum antiviral activity at nanomolar concentrations. Antimicrob. Agents Chemother. 2015, 59 (4), 2062-71.

5. Popowycz, F.; Fournet, G.; Schneider, C.; Bettayeb, K.; Ferandin, Y.; Lamigeon, C.; Tirado, O. M.; Mateo-Lozano, S.; Notario, V.; Colas, P.; Bernard, P.; Meijer, L.; Joseph, B., Pyrazolo[1,5-a]-1,3,5-triazine as a Purine Bioisostere: Access to potent cyclin-dependent kinase inhibitor (R)-roscovitine analogue. J. Med. Chem. 2009, 52 (3), 655-663.

6. Nekardova, M.; Vymetalova, L.; Khirsariya, P.; Kovacova, S.; Hylsova, M.; Jorda, R.; Krystof, V.; Fanfrlik, J.; Hobza, P.; Paruch, K., Structural Basis of the Interaction of Cyclin-Dependent Kinase 2 with Roscovitine and Its Analogues Having Bioisosteric Central Heterocycles. ChemPhysChem 2017, 18 (7), 785-795.

7. (a) Bettayeb, K.; Baunbaek, D.; Delehouze, C.; Loaec, N.; Hole, A. J.; Baumli, S.; Endicott, J. A.; Douc-Rasy, S.; Benard, J.; Oumata, N.; Galons, H.; Meijer, L., CDK inhibitors roscovitine and CR8 trigger Mcl-1 down-regulation and apoptotic cell death in neuroblastoma cells. Genes Cancer 2010, 1 (4), 369-380; (b) El Hage, K.; Piquemal, J.-P.; Oumata, N.; Meijer, L.; Galons, H.; Gresh, N., A Simple Isomerization of the Purine Scaffold of a Kinase Inhibitor, Roscovitine, Affords a Four- to Seven-Fold Enhancement of Its Affinity for Four CDKs. Could This Be Traced Back to Conjugation-Induced Stiffenings/Loosenings of Rotational Barriers? ACS Omega 2017, 2 (7), 3467-3474. 
8. Wu, M.; White, H. V.; Boehm, B. A.; Meriney, C. J.; Kerrigan, K.; Frasso, M.; Liang, M.; Gotway, E. M.; Wilcox, M. R.; Johnson, J. W.; Wipf, P.; Meriney, S. D., New Cav2 calcium channel gating modifiers with agonist activity and therapeutic potential to treat neuromuscular disease. Neuropharmacology 2018, 131, 176-189.

9. (a) Lim, F. P. L.; Halcovitch, N. R.; Tiekink, E. R. T.; Dolzhenko, A. V., A new microwaveassisted, three-component reaction of 5-aminopyrazole-4-carboxylates: Selective synthesis of substituted 5-aza-9-deaza-adenines. Tetrahedron 2018, 74 (15), 1868-1879; (b) Lim, F. P. L.; Kow, K. K.; Yeo, E. H.; Chow, S. C.; Dolzhenko, A. V., Synthesis and antileukemic activity of new fluorinated 5-aza-9-deazapurines. Heterocycles, 2016, 92 (6), 1121-1131; (c) Lim, F. P. L.; Luna, G.; Dolzhenko, A. V., A one-pot, three-component aminotriazine annulation onto 5aminopyrazole-4-carbonitriles under microwave irradiation. Tetrahedron Lett. 2015, 56 (3), 521-524; (d) Lim, F. P. L.; Luna, G.; Dolzhenko, A. V., A one-pot, three-component, microwave-assisted synthesis of novel 7-amino-substituted 4-aminopyrazolo[1,5a][1,3,5]triazine-8-carbonitriles. Tetrahedron Lett. 2015, 56 (50), 7016-7019; (e) Lim, F. P. L.; Luna, G.; Dolzhenko, A. V., A new, one-pot, multicomponent synthesis of 5-aza-9-deazaadenines under microwave irradiation. Tetrahedron Lett. 2014, 55 (37), 5159-5163; (f) Lim, F. P. L.; Dolzhenko, A. V., 4-Amino-substituted pyrazolo[1,5-a][1,3,5]triazin-2-amines: a new practical synthesis and biological activity. Tetrahedron Lett. 2014, 55(49), 6684-6688.

10. OIDD screening data supplied courtesy of Eli Lilly and Company - used with Lilly's permission.

11. Lim, F. P. L.; Gan, R. X. Y.; Dolzhenko, A. V., Highly selective and efficient synthesis of 3arylamino-substituted 5-aminopyrazole-4-carboxylates under microwave irradiation. Tetrahedron Lett. 2017, 58(8), 775-778.

12. See the preceding paper in this issue: Lim, F. P. L.; Tan, K. C.; Luna, G.; Tiekink, E. R. T.; Dolzhenko, A. V., A new practical synthesis of 3-amino-substituted 5-aminopyrazoles and their tautomerism. Tetrahedron 2019, 75(15), 2314-2331.

13. Szymański, S.; Gryff-Keller, A., Analysis of DNMR lineshape by an iterative least-squares method. J. Magn. Reson. 1976, 22 (1), 1-5.

14. Rigaku Oxford Diffraction, CrysAlis PRO, Yarnton, Oxfordshire, England (2017). 
15. Sheldrick, G. M., Acta Crystallogr., Sect. A: Found. Crystallogr., 2008, 64, 112-122.

16. Farrugia, L. J., J. Appl. Crystallogr., 2012, 45, 849-854.

17. Sheldrick, G. M., Acta Crystallogr., Sect. C: Struct. Chem., 2015, 71, 3-8.

18. Brandenburg, K., DIAMOND, Crystal Impact GbR, Bonn, Germany, 2006.

19. Spek, A. L., Acta Crystallogr. Sect. D: Biol. Crystallogr., 2009, 65, 148-155. 